
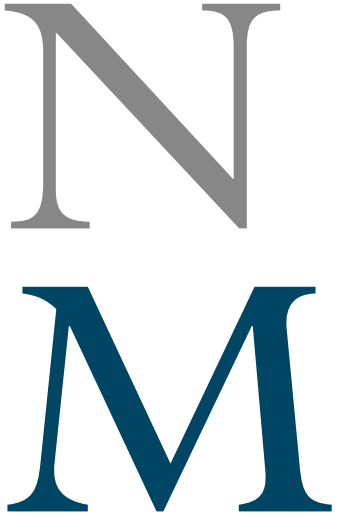
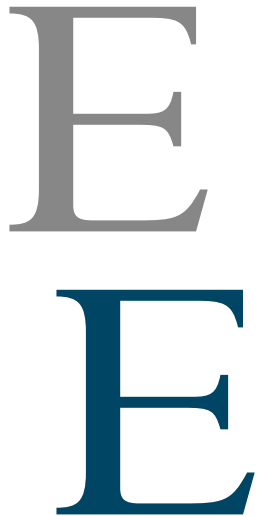
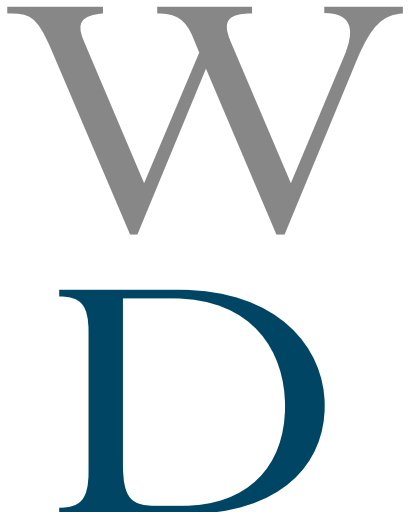
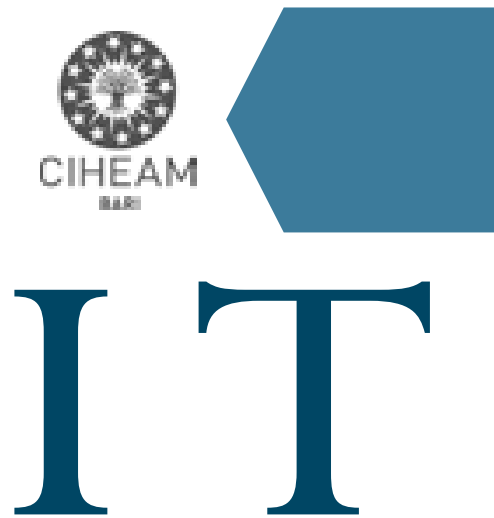

MEDITERRANEAN JOURNAL OF ECONOMICS, AGRICULTURE AND ENVIRONMENT

Poste Italiane Spa Spedizione in Abbonamento Postale Periodico ROC Centro Nord aut. $\mathrm{N}^{\circ} 0029-€ 15,00$.

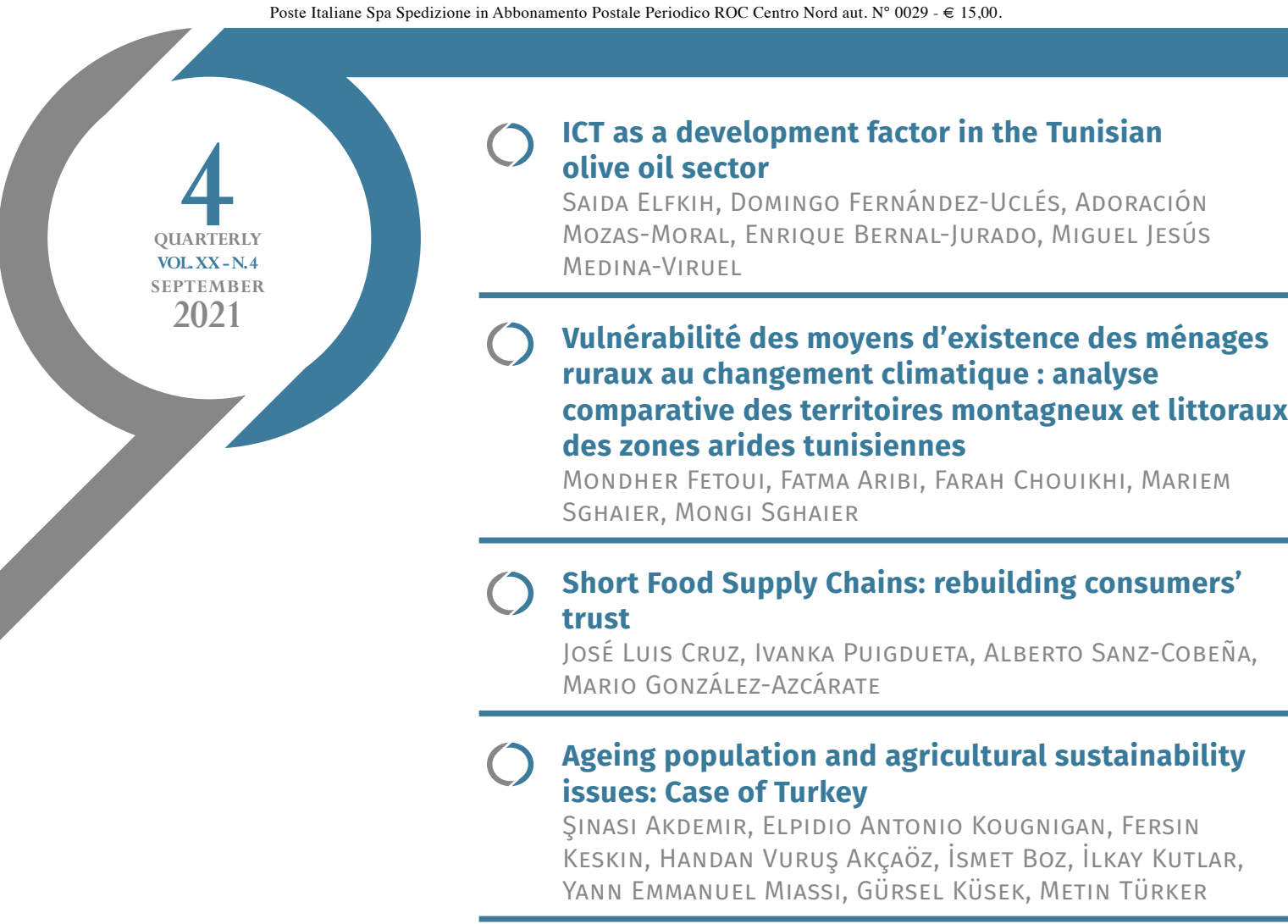




\title{
ICT as a development factor in the Tunisian olive oil sector
}

\section{Saida Elfkih*, Domingo Fernández-Uclés**, Adoración Mozas-Moral ${ }^{\star \star}$, Enrique Bernal-Jurado ${ }^{\star \star}$, Miguel Jesús Medina-Viruel ${ }^{\star \star *}$}

DOI: $10.30682 / \mathrm{nm} 2104 \mathrm{a}$

JEL codes: M15, O32, Q13

\begin{abstract}
Olive oil is one of the main agricultural products of the countries that make up the Mediterranean basin. The low profitability of this sector of activity and the growing challenges of an increasingly turbulent market force the sector to search for more efficient organization. The aim of this paper is to determine the organisational and technological factors associated with the most economically efficient Tunisian olive-growing organisations. To this end, firstly the Data Envelopment Analysis method has been used to establish a hierarchy of the most efficient organizations. Secondly, the Qualitative Comparative Analysis method has been used, which allows us to establish the relationships of variables that explain the highest levels of economic efficiency. The results obtained show that the academic training of the top manager, training in information technology, the age of the organisation and the existence of plans and budget items for the adoption of information and communication technologies are variables that explain this greater efficiency.
\end{abstract}

Keywords: Olive oil, Efficiency, DEA, fsQCA.

\section{Introduction}

Olive oil is a basic product of the so-called "Mediterranean diet". The world production of olive oil presents a continuous tendency of growth due to the technological improvements, the extension of the irrigation system and the gradual increase of the olive grove surface (Parras et al., 2013). Consumption is also increasing, due to the benefits and attributes of this product with respect to other existing oils and fats (Vilar and Cárdenas, 2016). In Tunisia the olive oil sector plays a very important role, both at the economic level and at the environmental and so- cial levels. The olive grove occupies $36 \%$ of the total arable land and $79 \%$ of the surface dedicated to arboriculture. It should be noted that 95\% of the Tunisian olive grove is a traditional crop, cultivated on dry land and with almost no input of chemical fertilizers, which has facilitated its conversion to the organic system. Thus, Tunisia is positioned as one of the largest producers and exporters of organic olive oil in the world (Ben Abdallah et al., 2018).

Within the commercial flow of agri-food products in Tunisia, olive oil occupies a leading position. In fact, $75 \%$ of the olive oil production

\footnotetext{
* Institute de l'Olivier, Sfax, Tunisia.

** University of Jaén. Campus Las Lagunillas, Jaén, Spain.

*** University of Córdoba. Facultad de Derecho y Ciencias Económicas y Empresariales, Puerta Nueva, s/n, 14071, Córdoba, Spain.

Corresponding author: dfucles@ujaen.es
} 
was destined to international markets during the period 2013-2018 (IOC, 2019). This situation is the result of public policies that encouraged "bulk" olive oil exports, with low added value. In fact, only a few countries of the European Union (the traditional markets), namely Italy, Spain and France, are the usual markets for the sale of oil from Tunisia. These target markets are currently much more diversified thanks to their new strategic orientation towards the modernization of the producing entities and towards the sale of olive oil with higher added value, either through bottling or marketing under different quality signs, such as the one that certifies the organic origin of the oils (Elfkih, 2013).

The predominance of the "bulk" sales format among the producing entities adds a serious commercial problem to this sector, which translates into a lack of orientation towards the final market. Few are the producing entities that control the entire value chain, except for some large producers, producers of organic olive oil, in addition to the agro-complexes belonging to the State (Elfkih and Karray, 2011). Currently, the sector has more than 1,750 mills, 15 refining plants, 14 olive-pomace oil extractors, more than 35 bottling plants and more than 200 private sector traders and exporters, together with the national oil office and the state public domains (IOC, 2017). However, this sector faces many challenges and still has a long way to go before it can be modernized, because the continuity of its exports, its capacity to defend itself against competition and the maintenance of its profitability are not guaranteed.

In improving trade, the use of and commitment to technology can play a fundamental role. The development of information and communication technologies (henceforth ICTs), with the use of the Internet and the tools it integrates, has brought about a technological revolution in the use and distribution of information. ICTs are a powerful competitive tool and, above all, an indispensable requirement for successfully competing in today's market (Kaplan and Haenlein, 2010; Bernal et al., 2019). The presence of an increasingly technological society explains the relevance of using these media, especially the Internet, where more than 55 percent of the world's population is present ${ }^{1}$. Various theories, such as that of transaction costs, have been used as a basis for arguing the benefits of these technologies for business performance (Mozas-Moral et al., 2016). Indeed, information, negotiation and guarantee costs have been reduced by the use of these means, allowing the organization to provide a more economical, personalized and flexible service to consumers (Stephen and Toubia, 2010; Karoui et al., 2015).

It follows that the use of ICTs should contribute to improving the performance of firms investing in this type of asset. However, the empirical work carried out does not show conclusive results regarding this relationship. The dominant academic literature has documented numerous studies that examine the relationship between investments in technology and the benefits obtained in terms of improved organizational performance (Brynjolfsson and Yang, 1996; Kohli and Devaraj, 2003). The results obtained so far have been contradictory (Lee, 2001; Lichtenberg, 1995) and range from pessimistic positions on the contribution of ICT to business performance (Solow, 1987; Strassmann, 1990) to more optimistic positions in recent times (Brynjolfsson and Hitt, 1996, 2003). These positions have generally focused on the so-called "productivity paradox" (Brynjolfsson, 1993), which describes the phenomenon seen in the 1970s and 1980s whereby firms that invested more in ICTs suffered a relative decline in labor productivity.

Many efficiency studies have been conducted on the agrifood sector and the factors that favor it (Vidal Giménez et al., 2000; Dios Palomares et al., 2006), but few have focused on the relationship between ICT and efficiency in this sector. Among the latter, it is worth mentioning the study by Medina et al. (2016), which dealt with the relationship between efficiency and the use of ICT in the organic olive oil sector.

This context justifies the need to identify the most efficient organizations, in order to deter-

1 Available at: https://www.internetworldstats.com/stats.htm. Revised February 2020. 
mine common patterns that can explain these best organizational practices. Thus, the objective of this study is to analyze Tunisian olive entities in terms of economic efficiency, in order to determine organizational and technological variables that are directly associated with greater efficiency. The methods used to achieve this objective have been the Data Envelopment Analysis (hereinafter DEA) and fuzzy sets Qualitative Comparative Analysis (hereinafter fsQCA) techniques. The present study is structured as follows: after this introduction, the contextual framework is presented, detailing the proposals of this paper; subsequently, the population and methodology are detailed; then, a section of results and discussion is presented; and finally, the corresponding conclusions are presented.

\section{Theoretical framework}

\subsection{The Tunisian olive oil sector}

Olive cultivation plays a very important social role in Tunisia, with more than 309,000 growers accounting for $20 \%$ of the active population in the primary sector (Agridata, 2019). Furthermore, this sector significantly strengthens the industrial and commercial infrastructure of the country. It currently boasts more than 1,750 oil mills, 15 refining plants, 14 olive pumice oil extractors, over 35 bottling plants and more than 200 private sector traders and exporters, as well as the national oil office and state-owned public domains (IOC, 2020). There are few producers that have control over the whole value chain except for a handful of large producers, organic producers and state-owned agro-complexes (Elfkih et al., 2011).

Olive oil is a strategic product both for Tunisian agriculture and for its economy as a whole. Indeed, it is the first agri-food product to be exported. In the last five years (2015-2019) the production of olive oil has been estimated at 196,000 tons of which 165,000 tons have been exported, representing $84 \%$ of the total produced. The volume of oil exported by Tunisia represents $20 \%$ of world exports (without taking into account intra-community exports) (IOC, 2019). The export of olive oil occupies first place in the Tunisian agro-food trade balance, both in quantity and in value of exports, and represents more than $50 \%$ of the total value of the agrofood exports of this country (Institut National de Statistique Tunisien, 2019). With an average value of 1,277 million Tunisian dinars (average 2014/2018) (Institut National de Statistique Tunisien, 2019), olive oil exports represent about $5 \%$ of total Tunisian exports and about $1.4 \%$ of the country's GDP.

This situation is the result of public policies to incentivize olive oil exports. Until 1962, the domestic market for vegetable oils was fully supplied by olive oil produced in the country. From this date onwards the Tunisian government resorted to a policy of exporting olive oil in bulk and importing seed oils, with the twofold objective of protecting the purchasing power of low-income households and promoting olive oil exports. This policy made it possible, on the one hand, to stabilize the balance of payments, and on the other to promote the olive oil sector by widening the olive-growing area and modernizing the corresponding industrial infrastructure, increasing both processing and storage capacity (Saï and Msallem, 2005).

As a result of this policy and the preferential export deals signed with the EU in the 1980s, Tunisian olive oil exports saw a steady increase in their share of international markets, which currently stands at $19 \%$ of total world olive oil trade. However, for a long time these exports were highly concentrated geographically and were sold in bulk with low added value. Indeed, historically Tunisia only exported olive oil to a few EU countries (the traditional markets), namely Italy, Spain and France. These target markets are now much more diversified thanks to their new strategic approach of modernizing production facilities and adding greater value to the product, either through packaging or quality labels, such as the label that certifies organic origin (Elfkih, 2013).

In response to these new challenges the Tunisian olive oil sector now benefits from a national development strategy that aims to boost production and reduce fluctuations in annual output by expanding the growing area into more adequate soils, improving olive oil quality through 
the modernization of production processes, improving international market positioning to gain greater product visibility through diversifying end markets and targeting markets with greater added value, and improving export shares of bottled oil and organic olive oil. A series of innovative and promising measures and initiatives have been implemented to fulfil these objectives. In this regard, various funds have been set up to support export activity and provide a favorable framework for investors (IOC, 2020).

\subsection{Proposed development factors for the Tunisian olive sector}

In the current context, technological development is considered a key aspect for business success (Kaplan and Haenlein, 2010). In relation to the olive sector, the use of ICTs and the commitment to e-commerce have been identified as key factors for its modernization (Bernal et al., 2019). In the Tunisian olive sector, there is very little information on the role of ICTs in these organizations, their management and the level of training of those responsible for taking advantage of their potential. Among the few studies related to this topic we highlight those of Ben Ayed Mouelhi (2009), Kosai and Piget (2014), Sadok et al. (2016) and Bakir et al. (2018). The first three works cited highlight the importance of ICTs in Tunisian industrial organizations, as well as the role of ICTs as facilitators of new opportunities for socio-economic growth and regional balance. With regard to the olive oil sector, the work of Bakir et al. (2018), carried out on olive oil producing entities in the area of Sfax (Tunisia), highlights the extreme importance of the profile of the organization managers for the development of ICTs.

The figure of the maximum organizational leader has been frequently pointed out as a determining variable in the success of this business (Medina et al., 2016). Specifically, many studies have considered the academic training of the maximum leader a determining factor in the economic efficiency of the organization (Levie and Autio, 2011), since it will stimulate their commitment to innovation and the implementation of more efficient organizational practices
(Fernández-Uclés et al., 2020). Similarly, ICT training for top management is relevant in order for organizations to integrate these tools and improve their business performance (Nguyen and Barret, 2006). Managers with training in these technologies will be more aware of their importance and will devote more effort to their proper use and to their commitment to innovation, contributing to the improvement of the organization's economic efficiency (Kim and Jee, 2007). These arguments lead us to formulate the following proposals:

Proposition 1. The academic training of the head favours the economic efficiency of the organisation.

Proposition 2. The specific training in ICT of the head favours the economic efficiency of the organisation.

One source of competitive advantage comes from innovation, through its internal management (Gray, 2006). The presence of personnel trained and qualified in technological management will allow an efficient use of the different technological tools made possible by the Internet (Peansupap and Walker, 2006). In spite of this, the organizations of the olive oil sector generally lack internal personnel trained and qualified ad hoc in the management of these technologies (Fernández-Uclés et al., 2016). An alternative to this problem is outsourcing, to external professionals dedicated to this function (He et al., 2017). As opposed to the different existing alternatives, the most recommendable option is to have qualified professionals who manage these tools internally, in order to take full advantage of the potential offered by information and communication technologies (Rita and Sunny, 2012). This line of argument leads us to make the following proposal:

Proposition 3. Training in ICT for those responsible for managing these technologies contributes to the economic efficiency of the organization.

The age of the organization can also be considered a trigger for its innovative attitude (Díaz et al., 
2006). In this sense, authors such as Pavitt (2003) maintain that the organizations of greater antiquity can find greater difficulties in innovation, because they have adopted organizational and commercial automatisms that make them more reticent and, therefore, present a worse business performance (Cucculelli et al., 2014). Innovation and market orientation is an essential aspect of profitability in the agri-food sector (Gorgues et al., 2019). Similarly, it has also been noted that younger organizations are more prone to innovation and better adaptation to markets (Frenkel et al., 2001), which translates into better organizational practices and greater economic efficiency. In this regard, Czarnitzki and Delanote (2012) point out that young organizations are more likely to grow faster and consequently to perform better, especially those that are committed to innovation. Considering these arguments, we make the following proposal:

Proposition 4. The age of the organization is inversely related to the economic efficiency of the organization.

The study of the ICT planning process has traditionally focused on its influence on business results. Thus, Sohal et al. (2000) and Sieber et al. (2006) argue the importance of planning the use of ICTs in enterprises in order to employ them in the most efficient manner. For their part, other authors highlight the importance of the ICT plan being aligned with the organization's general strategy, with organizations adapting to these technologies and these, in turn, adapting to the organization's characteristics and general lines of action. Thus, these studies maintain that the ICT strategy and the company's general strategy must be in line (Hurley and Birkwood, 1997; Parra and Molinillo, 2001; Peppard and Ward, 2004; Hidalgo et al., 2008).

In the light of the studies carried out, it seems clear that ICT planning has a positive influence on profitability, without any studies that maintain a direct relationship between ICT planning and the possibility of adopting these technologies in the organization. However, in this study we consider that planning can be a key factor in organizations deciding to adopt this type of technology, based on the following arguments:
Proposition 5. The existence of plans and budget items for the adoption of ICT in the organization positively conditions the economic efficiency of the organization.

\section{Population and methods}

\subsection{Population}

The population under study is made up of Tunisian olive oil producers and marketers who have a presence on the Internet through their own websites. In order to obtain the registration of these operators we contacted the Tunisian Agency for the Promotion of Industry and Innovation, which is a public institution where all industrial and agro-food organizations are registered in order to benefit from subsidies, as well as from the support and monitoring of their projects. The total number of olive oil processors and marketers provided by this agency amounted to 351 organizations. An Internet search was then carried out to determine the number of organizations with their own website, resulting in a total of 90 organizations with a website. Therefore, these 90 organizations make up our study universe. Subsequently, a structured face-to-face survey was carried out for the top organizational managers and was answered by 47 organizations (52.22\% response rate).

\subsection{Methods}

For this research primary and secondary sources were used, reviewing the existing literature on the subject. Regarding the methodology used, firstly an economic efficiency analysis was carried out on the Tunisian olive-growing organisations, applying the Data Envelopment Analysis technique (hereinafter DEA). This method is reliable and valid for efficiency analysis, standing out for its popularity and widespread use (Kuosmanen et al., 2015; Liu et al., 2015). The purpose of this technique is to compare different homogeneous decision units by evaluating the influence of a series of production factors or inputs used in obtaining outputs, assigning a level of efficiency of between 0 and 1. Thus, based on linear programming and considering identical 
Table 1 - Average value of the variables considered in the economic efficiency model.

\begin{tabular}{|l|l|c|}
\hline \multicolumn{2}{|c|}{ Variables } & Average value \\
\hline Input & Personnel costs & $91,994 €$ \\
\hline Input & Expenditure on raw materials and materials & $6,371,712 €$ \\
\hline Input & Depreciation of tangible fixed assets & $34,400 €$ \\
\hline Output & Turnover & $8,845,954 €$ \\
\hline
\end{tabular}

Source: own data.

inputs and outputs, the entities that are totally efficient are determined (they obtain a score equal to 1) and are located in the so-called efficiency frontier (Samoilenko, 2014).

There are different developments of the DEA method, in particular the classical BCC model has been used, which evaluates inputs and outputs considering variable returns to scale (Charnes et al., 2013). An output orientation has also been chosen for the model proposed, which consists of focusing the efficiency approach on maximising outputs. This choice is due to the fact that we consider it more relevant to focus on the outputs of the process, due to the outstanding commercial problem faced by agricultural entities as well as to the agricultural nature of these entities, in which the inputs are partially subject to the seasonality of the crop. One of the main weaknesses of DEA lies in its sensitivity to extreme values (Charnes et al., 2013). To alleviate this handicap, the super-efficiency technique has been used, eliminating those values that exceed an efficiency threshold of 2 and can be considered outliers (Banker and Chang, 2006). As a result, the number of entities on which the DEA analysis is performed is 46 organizations.

The primal approach of DEA with the BCC-O model is: $\max \left(\varnothing, \lambda, \mathrm{s}^{+}, \mathrm{s}^{-}\right)$subject to the following conditions: ; ; In this case, if $\emptyset=1$, the unit is considered efficient, meaning that there is no other unit that produces more or that achieves the same output using fewer resources. If this model is used, all efficient units return the same value $(\varnothing=1)$, so it is not possible to establish a ranking. With the use of the super-efficiency method created by Andersen and Petersen (1993) this restriction is eliminated, therefore previous studies have taken advantage of this approach to remove very distant values considered outliers.
Continuing with this study, it is frequent to find a second phase that closes the DEA technique, to characterize or strengthen the results obtained. Among the different procedures used for this second phase of analysis, the use of regression models is common in order to know the contextual variables that explain the resulting efficiency scores (Charnes et al., 2013). Thus, an intense debate has been generated to identify the statistical procedure that best suits this purpose (Kuosmanen et al., 2015). In this paper, and with reference to this second stage of analysis, the Qualitative Comparative Analysis (QCA) technique has been used, employing the fuzzy set approach (fsQCA), in order to establish variables of a technological and organisational nature that are jointly associated with a higher level of efficiency. It is precisely these DEA efficiency indices that will act in this second phase of analysis as a dependent variable.

The average values of the variables used to carry out the DEA method are presented (Table 1). As can be seen in Table 1, these variables correspond to a classical model of economic efficiency on the Tunisian olive sector. In order to increase the rigour of this study and reduce the variability of the organisational results, which are the result of the crop's variability, an average of the values of these variables has been calculated considering three consecutive years, corresponding to the campaigns 2014, 2015 and 2016.

To deepen this analysis, which consists of identifying the organizational and technological variables associated with a higher economic efficiency score, the fuzzy sets Qualitative Comparative Analysis (fsQCA) technique has been used. QCA uses a verbal, conceptual and mathematical language that configures it as a qualitative and quantitative approach, combin- 
Table 2 - Variables considered for the fsQCA technique.

\begin{tabular}{|l|ll|}
\hline Outcome & \multicolumn{2}{|c|}{ Description } \\
\hline BCC scores & Results of DEA economic efficiency model & Continuous variable \\
\hline Causal condition & \multicolumn{2}{|c|}{ Description } \\
\hline Education & Education level of managing director & Categorical variable $^{\mathrm{a}}$ \\
\hline ICT.director & ICT training of managing director & Categorical variable $^{\mathrm{b}}$ \\
\hline ICT.staff & ICT training for staff & Categorical variable $^{\mathrm{b}}$ \\
\hline Age & Longevity of organization & Continuous variable \\
\hline ICT.plan & ICT planning & Dichotomous variable \\
\hline ICT.investment & Invest in ICT & Dichotomous variable \\
\hline
\end{tabular}

${ }^{a}$ Five-level categorical variable (no education; primary level; secondary level; first-level university degree; second-level university degree). Calibrated according to Rihoux and Ragin (2009).

${ }^{b}$ Four-level categorical variable (no knowledge; user level; intermediate level; advanced level). Calibrated according to Rihoux and Ragin (2009).

Source: own data.

ing the main advantages of these (Ragin, 1987). Thus, by applying QCA it is possible to systematically analyze a set of cases, to determine causal patterns in the form of need and sufficiency relationships between a set of conditions and an outcome (Schneider and Wagemann, 2010). The development of fuzzy sets (fsQCA) is one of the most widely used variants of QCA, as it resolves one of the main drawbacks and criticisms of the initial approach called csQCA, which is its strictly dichotomous approach (Sehring et al., 2013).

The fsQCA technique was developed for small sample sizes or populations (Ragin, 1987), so it does not pose a problem for this research, in which the study universe is small. This technique offers as a result one or several antecedent combinations sufficient to obtain a specific result such as: $\mathrm{X} 1 * \sim \mathrm{X} 2 * \mathrm{X} 3$ sufficient for outcome (Y), or expressed in the notation system of this method $(\mathrm{X} 1 * \sim \mathrm{X} 2 * \mathrm{X} 3 \rightarrow \mathrm{Y})$, where $\mathrm{X} 1, \mathrm{X} 2$ and $\mathrm{X} 3$ are antecedents; $\mathrm{Y}$, the outcome; * indicates "AND"; and absence or negation, in this case the opposite value to $\mathrm{X} 2$ (1- X2). For the correct execution of this technique the phases recommended in the literature are followed (Schneider and Wagemann, 2012): calibration of the variables that require it, both of the conditions and of the result; analysis of necessity; and analysis of sufficiency.
Thus, the economic efficiency scores obtained with the DEA method are the dependent or outcome variable considered. On the other hand, the independent variables that have been proposed are detailed in Table 2.

\section{Results}

The economic efficiency results obtained after applying the DEA technique, according to the output-oriented BCC model, are detailed in Table 3 . Firstly, six organizations out of 45 analyzed are considered efficient, forming the wellknown efficiency frontier. The number of efficient organisations can be considered low, at 13.33 percent. The average efficiency of the organisations that are not considered efficient (not reaching a value of 1 ) is 0.60 , with a standard deviation of 0.23 , which reveals a high variation between the efficiency scores obtained by the different organisations analyzed.

Table 3 - Economic efficiency results.

\begin{tabular}{|lc|}
\hline Number of efficient DMUs & 6 \\
\hline Percentage of efficient DMU & $13,33 \%$ \\
\hline Average efficiency & 0,60 \\
\hline Standard deviation & 0,23 \\
\hline Inefficiency on average & 0,40 \\
\hline
\end{tabular}

Source: own data. 
Table 4 - Results of fsQCA analysis.

\begin{tabular}{|l|c|c|c|c|}
\hline Solutions & 1 & 2 & 3 & 4 \\
\hline education & $\bullet$ & $\bullet$ & & $\bullet$ \\
\hline ICT.director & $\bullet$ & & $\bullet$ & $\bullet$ \\
\hline ICT.staff & & & $\bullet$ & $\bullet$ \\
\hline Age & & $\bullet$ & $\bullet$ & $\bullet$ \\
\hline ICT.plan & $\bullet$ & $\bullet$ & 0.372268 & 0.354668 \\
\hline ICT.investment & $\bullet$ & 0.544514 & 0.030318 & 0.050182 \\
\hline Gross coverage & 0.677153 & 0.015824 & 0.848682 & 0.863622 \\
\hline Single coverage & 0.166837 & 0.828038 & & \\
\hline Consistency & 0.871282 & & & \\
\hline Solution coverage & 0.837849 & & \\
\hline Solution consistency & 0.776811 & & \\
\hline
\end{tabular}

Source: own data.

The results of the BCC O efficiency analysis show that a very small group of organisations can be considered efficient, namely 13.33 percent. Characterizing these organizations with higher values of economic efficiency it is observed that they respond to large entities, which develop a greater control over the value chain, as is the case of the State's agro-complexes. This control entails a complete quality control process, which has an immediate and positive effect on the volume of turnover, as well as a greater control over raw material expenses (Elfkih and Karray, 2011).

The results of this second stage of the study, in which the fsQCA method is applied, are shown in Table 4. The resulting causal configurations have been ordered from highest to lowest according to their gross coverage. For the presentation of the results, the configurations use black circles to indicate the presence of the condition $(\bullet)$, white circles to indicate the absence of the condition $(0)$ and the absence of a circle indicates that the condition is not binding in that configuration. The first configuration covers a gross coverage of 0.677153 , indicating the relations between the manager's academic training and his/her ICT training and the existence of plans and budgetary items for the adoption of ICTs as a set of variables that explain greater economic efficiency. Similarly, it is worth highlighting the second casual configuration, which again includes the manager's academic training, the existence of plans and budgetary items and inversely, seniority, with a gross coverage level of 0.544514 .

The global solution of this model gives a coverage of 0.837848 , which denotes the proportion of organizations that are explained by the variables considered, and a total consistency of 77.68 percent of the cases. The results obtained are in line with those of other previous studies that have demonstrated the existence of a positive impact of the use of ICTs and the academic training of the CEO or leader on the efficiency of Tunisian organizations.

\section{Conclusions and discussion}

This study encourages Tunisian olive oil agrofood organizations, and in general the olive oil agro-food business network, to increase their commitment to innovation and the use of new ICTs as a means of growth, development and economic efficiency. It has become clear that the incorporation of these technologies in the olive sector is a decisive competitive factor in guaranteeing the survival and profitability of the organization, as well as in responding to the challenges brought about by this digital transformation (Jorge-Vázquez et al., 2019). The use of virtual social networks, as well as other means incorporated by the Internet, are essential elements to 
be incorporated into business management, in order to respond with guarantees to the current environment (Borrero, 2019; Corrons and Gil, 2019). In this way the presence of a website, as a reception point for Internet users, the existence of a virtual store, such as an online sales channel, and the use of virtual social networks as a communication channel and relationship marketing strategy, are low-cost elements that can increase the competitiveness of this sector and therefore its profitability.

The results obtained in the economic efficiency analysis by DEA show that only a very small number of Tunisian olive-growing entities can be considered efficient. The organisations that are outside the efficiency frontier have economic efficiency indices that can be designated as low. The fsQCA analysis has highlighted the importance of the variables proposed as explanatory factors for the higher economic efficiency scores, allowing the validation of the proposals initially put forward. In fact, Ben Ayed Mouelhi (2009) confirms that organizations that make intensive use of ICTs have greater technical efficiency than other organizations.

The combinations of variables associated with the most efficient organizations, in economic terms, allow us to conclude the following: The descriptors of better economic results are those organisations that are directed and have personnel trained in ICTs. The incorporation of these technologies in the olive sector is a response to the challenges brought about by this digital transformation and a decisive competitive factor in guaranteeing the survival and profitability of the organisation (Jorge-Vázquez et al., 2019). Seniority is not a handicap if Tunisian olive oil organizations have personnel trained in these technologies, which allows them to take full advantage of the potential of these social and technological tools. As a recommendation we suggest encouraging the use of ICT in companies for commercial purposes, and not only with the presence of these tools, but with a planning strategy and human capital trained to maximize their contribution to the efficiency of the company.

The limitations that can be attributed to this study are the following: the general econom- ic efficiency model proposed, despite being a common one in this type of study, may not bring together all the relevant variables that accurately determine the best organizational practices. However, its reliability has been demonstrated in the literature by bringing together the main economic items associated with the organisation. If the intention is to generalize these results to the agri-food sector, it is a limitation that this research should focus exclusively on the entities of the olive sector. However, the whole agrifood sector presents, in general terms, a similar problem in terms of marketing. Therefore, we believe that these results can be extrapolated to a large part of this sector.

This research opens up an immense field of work for future investigations. Among them we can highlight the following: deepening the study of which structural and organisational variables favour market orientation through virtual social networks or other ICT applications and determining whether this explanatory model coincides in other sectors of agrifood.

\section{References}

Agridata, 2019. Ministère de l'Agriculture, des Ressources Hydrauliques et de la Pêche. Available at: http://www.agridata.tn/fr. Revised in January 2021.

Andersen P., Petersen N.C., 1993. A Procedure for Ranking Efficient Units in Data Envelopment Analysis. Management Science, 39: 1261-1264.

Ati S., Mhiri Eleuch N., 2013. Stratégies d'alliance et efficience économique des Petites et Moyennes Entreprises (PME) tunisiennes. Analyse par la méthode DEA. La Revue des Sciences de Gestion, 259-260(1-2): 39-51.

Bakir S., Elfkih S., Bernal E., Mozas A., 2018. Exploitation des Technologies de l'Information et de la Communication et du E-Commerce dans le secteur oléicole tunisien : Cas de la région de Sfax. Revue des Régions Arides, 44(1): 461-471.

Banker R.D., Chang H., 2006. The super-efficiency procedure for outlier identification, not for ranking efficient Units. European Journal of Operational Research, 175(2): 1311-1320.

Ben Abdallah S., Elfkih S., Parras-López C., 2018. A sustainability comparative assessment of Tunisian organic and conventional olive growing systems based on the AHP methodology. New Medit, 17(3): 51-68. 
Ben Ayed Mouelhi R., 2009. Impact of the adoption of information and communication technologies on firm efficiency in the Tunisian manufacturing sector. Economic Modelling, 26: 961-967.

Bernal-Jurado E., Mozas-Moral A., Fernández-Uclés D., Medina-Viruel M.J., Puentes-Poyatos R., 2019. Calidad de los sitios web en el sector agroalimentario ecológico y sus factores explicativos: el papel del cooperativismo. CIRIEC-España, Revista de Economía Pública, Social y Cooperativa, 95: 95118. DOI: 10.7203/CIRIEC-E.95.13207.

Borrero J.D., 2019. Agri-food Supply Chain Traceability for Fruit and Vegetable Cooperatives Using Blockchain Technology. CIRIEC-España, Revista de Economía Pública, Social y Cooperativa, 95: 71-94. DOI: 10.7203/CIRIEC-E.95.13123.

Brynjolfsson E., 1993. The productivity paradox of information technology. Communications of the $A C M, 36(12)$ : 66-77.

Brynjolfsson E., Hitt L., 1996. Paradox lost? Firm-level evidence on the returns to information systems spending. Management Science, 42(4): 541-558.

Brynjolfsson E., Hitt L., 2003. Computing productivity: Firm-level evidence. Review of economics and statistics, 85(4): 793-808.

Brynjolfsson E., Yang S., 1996. Information technology and productivity: a review of the literature. $A d$ vances in computers, 43: 179-214.

Charnes A., Cooper W.W., Lewin A.Y., Seiford L.M. (eds.), 2013. Data envelopment analysis: Theory, methodology, and applications. New York: Springer Science \& Business Media.

Corrons A., Gil M., 2019. Is blockchain technology compatible with the Social and Solidarity Economy? Towards a new paradigm. CIRIEC-España, Revista de Economía Pública, Social y Cooperativa, 95: 191-215. DOI: 10.7203/CIRIEC-E.95.12984.

Cucculelli M., Mannarino L., Pupo V., Ricotta F., 2014. Owner-Management, Firm Age, and Productivity in Italian Family Firms. Journal of Small Business Management, 52(2): 325-343.

Czarnitzki D., Delanote J., 2012. Young innovative companies: the new high-growth firms? Industrial and Corporate Change, 22(5): 1315-1340.

Díaz Díaz N.L., Aguiar Díaz I., De Saá Pérez P., 2006. El conocimiento organizativo tecnológico y la capacidad de innovación: evidencia para la empresa industrial española. Cuadernos de Economía y Dirección de la Empresa, 27: 33-59.

Dios Palomares R., de Haro Giménez T., Martínez Paz J.M., 2006. Eficiencia técnica en el sector oleicola. Un nuevo método con factores ambientales. Documento de trabajo Serie Economía E2006/01,
Centro de Estudios Andaluces, Consejería de la Presidencia.

Elfkih S., 2013. Economie Oléicole et Stratégie de Développement. In: Guide de l'huile d'olive en Tunisie: l'huile d'olive éclaire la Tunisie depuis Carthage. Edition Ministère de l'Industrie de la Tunisie et l'Institut de l'Olivier, pp. 97-111.

Elfkih S., Karray B., 2011. Les différentes structures de production de l'huile d'olive biologique dans la région de Sfax: une analyse comparative. Revue Azzaytouna, 12(1): 13-27.

Elfkih S., Mozas-Moral A., Bernal-Jurado E., Karray B., Abichou M., Martínez Gutiérrez A., Torres Ruiz F.J., Guzmán Vico A., 2011. Situación actual de la organización del sector tunecino del aceite de oliva y sus retos futuros. Expoliva, 13-15 Mai, Jaén (Espagne).

Fernández-Uclés D., Bernal-Jurado E., Mozas-Moral A., Medina-Viruel M.J., 2020. The importance of websites for organic agri-food producers. Economic Research-Ekonomska Istraživanja, 33(1): 2867-2880.

Fernández-Uclés D., Bernal-Jurado E., Mozas-Moral A., Medina-Viruel M.J., Moral-Pajares E., 2016. El sector cooperativo oleícola y el uso de las TIC: un estudio comparativo respecto a otras formas jurídicas. REVESCO: Revista de Estudios Cooperativos, 120: 53-75.

Frenkel A., Shefer D., Koschatzky K., Walter G.H., 2001. Firm characteristics, location and regional innovation: A comparison between Israeli and German industrial firms. Regional Studies, 35(5): 415-429.

Gorgues A.C., Sánchez P.C., Guiu R.F., 2019. Cooperativismo agroalimentario en Europa. Dimensión, gobernanza y análisis BCG de las sociedades cooperativas TOP25 de la UE-28 y TOP10 en España. REVESCO: Revista de estudios cooperativos, 130: 73-98.

Gray R., 2006. Social, environmental and sustainability reporting and organisational value creation? Whose value? Whose creation? Accounting, Auditing \& Accountability Journal, 19(6): 793-819.

He W., Wang F.K., Chen Y., Zha S., 2017. An exploratory investigation of social media adoption by small businesses. Information Technology and Management, 18(2): 149-160.

Hidalgo A., Vizán A., Torres M., 2008. Las claves de la innovación tecnológica: claves de la competitividad empresarial. Dirección y organización, 36: 5-22.

Hurley B., Birkwood P., 1997. Análisis y plan del negocio en Internet. Harvard Deusto Márketing y Ventas, 21: 27-29. 
Institut National de Statistique Tunisien, 2019. Balance Commerciale. Available at: http://www.ins.tn/ fr/themes/commerce-ext\%C3\%A9rieur\#3056. Revised in January 2021.

IOC (International Olive Council), 2017. OLIVAE. Revista oficial del Consejo Oleícola Internacional. 124, special issue dedicated to Tunisia. Available at: http://www.internationaloliveoil.org/store/ view/117-olivae-124-espanol?lang=es_ES. Reviewed in July 2020.

IOC (International Olive Council), 2019. Aceites de Oliva 2019. Available at: http://www.internationaloliveoil.org/estaticos/view/131-world-olive-oilfigures. Revised in January 2021

IOC (International Olive Council), 2020. OLIVAE. Revista oficial del Consejo Oleícola Internacional. 124, special issue dedicated to Tunisia. Available at: http://www.internationaloliveoil.org/store/ view/117-olivae-124-espanol?lang=es_ES.

Jorge-Vázquez J., Chivite Cebolla M Ma .P., Salinas Ramos F., 2019. La transformación digital en el sector cooperativo agroalimentario español: situación y perspectivas. CIRIEC-España, Revista de Economía Pública, Social y Cooperativa, 95: 3970. DOI: 10.7203/CIRIEC-E.95.13002.

Kaplan A.M., Haenlein M., 2010. Users of the world, unite! The challenges and opportunities of Social Media. Business horizons, 53(1): 59-68.

Karoui M., Dudezert A., Leidner D.E., 2015. Strategies and symbolism in the adoption of organizational social networking systems. The Journal of Strategic Information Systems, 24(1): 15-32.

Kim M.K., Jee K.Y., 2007. Factors influencing strategic use of information technology and its impact on business performance of SMEs. ETRI Journal, 29(4): 497-506.

Kohli R., Devaraj S., 2003. Measuring information technology payoff: A meta-analysis of structural variables in firm-level empirical research. Information systems research, 14(2): 127-145.

Kosai M., Piget P., 2014. Adoption of information and communication technology and firm profitability: Empirical evidence from Tunisia SMEs. Journal of High Technology Management Research, 25: 9-20.

Kuosmanen T., Johnson A., Saastamoinen A., 2015. Stochastic nonparametric approach to efficiency analysis: a unified framework. In: Zhu J. (ed.), Data Envelopment Analysis. New York: Springer, pp. 191-244.

Lee C.S., 2001. Modeling the business value of information technology. Information \& Management, 39(3): 191-210.
Levie J., Autio E., 2011. Regulatory burden, rule of law, and entry of strategic entrepreneurs: An international panel study. Journal of Management Studies, 48(6): 1392-1419.

Lichtenberg F.R., 1995. The output contributions of computer equipment and personnel: A firm-level analysis. Economics of innovation and new technology, 3(3-4): 201-218.

Liu J.S., Lu L.Y., Lu W.M., 2015. Research fronts in data envelopment analysis. Omega, 58: 33-45.

Medina-Viruel M.J., Bernal-Jurado E., Mozas-Moral A., Moral-Pajares E., Fernández-Uclés D., 2016. Efficiency of organic farming companies that operate in an online environment. Custose@gronegocio, 11(4): 264-289.

Mozas-Moral A., Bernal-Jurado E., Fernández-Uclés D., Medina-Viruel M.J., 2016. Web quality as a determining factor in the online retailing of organic products in Spain. New Medit, 15(2): 28-36.

Nguyen T.D., Barret N.J., 2006. The adoption of the Internet by export firms in transitional markets. Asia Pacific Journal of Marketing and Logistics, 18 (1): 29-42.

Parra F., Molinillo S., 2001. Marketing relacional y actividad comercial en los centros urbanos. ESIC Market, 109: 33-62.

Parras M., Torres F.J., Mozas A., 2013. El comportamiento comercial del cooperativismo oleícola en la cadena de valor de los aceites de oliva en España. In: Briz J., de Felipe I. (eds.), Metodología y funcionamiento de la cadena de valor alimentaria: un enfoque pluridisciplinar e internacional. Madrid: Editorial Agrícola Española.

Pavitt K., 2003. The process of innovation. In: Mowery J.D., Nelson R. (eds.), Handbook on innovation. Oxford: Oxford University Press.

Peansupap V., Walker D.H., 2006. Innovation diffusion at the implementation stage of a construction project: a case study of information communication Technology. Construction management and economics, 24(3): 321-332.

Peppard J., Ward J., 2004. Beyond strategic information systems towards an IS capability. Journal of Strategic Information Systems, 13(2): 167-194.

Ragin C.C., 1987. The comparative method: Moving beyond qualitative and quantitative strategies. Berkeley: University of California Press.

Rihoux B., Ragin C.C., 2009. Configurational comparative methods: Qualitative comparative analysis (QCA) and related techniques. Thousand Oaks: Sage.

Rita L., Sunny W.H., 2012. How companies cultivate relationships with publics on social network sites: 
Evidence from China and the United States. Public Relations Review, 38(5): 723-730.

Sadok M., Chatta R., Bednar P., 2016. ICT for development in Tunisia. Going the last mile. Technology in Society, 46: 63-69.

Saï B., Msallem M., 2005. Le secteur oléicole en Tunisie: de la protection à la libéralisation. In: Ceña $\mathrm{F}$., Elloumi M., Gallardo R., El Béchir Sai M. (eds.), Les défis de la terre: l'agriculture en Espagne et en Tunisie face au défis de la libéralisation, ouvrage collectif. Tunis: Cérès Editions et IRESA, pp. 203-222.

Samoilenko S., 2014. Overview on Data Envelopment Analysis. In: Osei-Bryson K.M., Ngwenyama O. (eds.), Advances in Research Methods for Information Systems Research. New York: Springer, pp. 139-150.

Schneider C.Q., Wagemann C., 2010. Standards of good practice in qualitative comparative analysis (QCA) and fuzzy-sets. Comparative Sociology, 9(3): 397-418.

Schneider C.Q., Wagemann C., 2012. Set-theoretic methods for the social sciences: A guide to qualitative comparative analysis. Cambridge: Cambridge University Press.

Sehring J., Korhonen-Kurki K., Brockhaus M., 2013. Qualitative Comparative Analysis (QCA): An application to compare national REDD+ policy processes. Working paper 121. Bogor, Indonesia: CIFOR.
Sieber S., Porta V., Valor J., 2006. Los sistemas de información en la empresa actual: aspectos estratégicos y alternativas tácticas. Madrid: McGraw-Hill Interamericana de España.

Sohal A.S., Moss S., Ng L., 2000. Using information technology productively: practices and factors that enhance the success of information Technology. International Journal of Technology Management 20(3): 340-344.

Solow R.M., 1987. We'd better watch out. New York Times Book Review, 36.

Stephen A.T., Toubia O., 2010. Deriving value from social commerce networks. Journal of Marketing Research, 47(2): 215-228.

Strassman P.A., 1990. The Business Value of Computers. New Canaan, CT: Information Economics Press.

Vidal Giménez F., Garcia del Río B.S., del Campo Gomis F.J., 2000. Eficiencia de las cooperativas de comercialización hortofrutícola de la Comunidad Valenciana. Revista Espanola de Estudios Agrosociales y Pesqueros, 188: 205-223.

Vilar J., Cárdenas J.R., 2016. El sector internacional de elaboración de aceite de oliva. Un estudio descriptivo de los 56 países productores. Jaén: GEA Centro Internacional de Excelencia para Aceite de Oliva. 